\title{
The Arrival and Diffusion of Academic Medicine in Rural Sweden: The Case of the Sundsvall Region in the late Nineteenth Century
}

\author{
Stephan Curtis
}

This study examines the numerous logistical, cultural and psychological obstacles that midwives had to overcome before women in the Sundsvall region of Sweden would entrust them to deliver their infants. By extension, this analysis reveals the tenuous position academic medicine had in many remote villages. These well-trained women benefitted from numerous pieces of legislation designed to enable them to replace the help-women who remained their greatest rivals. None the less, trained doctors and midwives often encountered resistance among local populations. Historians have tended to focus attention on the work of individual physicians and the consequences of government intervention without paying much attention to the patients themselves and the reasons they either accepted or rejected the people sent to provide medical care. This paper represents an attempt to address this imbalance by suggesting how theories of diffusion, concepts of trust, and perceptions of risk can help us understand the decisions made by people confronted with new medical practitioners.

Diffusion theory provides an opportunity to illuminate the process by which the acceptance of academic medicine, here represented by an increased willingness to have midwives attend births, diffused through the Sundsvall region of Sweden during the second half of the nineteenth century. Certainly the role of formal legislation, medical associations, and the practices of individual medical practitioners were critical to the introduction of new innovations. No one should dismiss the integral role these agents played in making academic medicine available to the public. ${ }^{1}$ Unfortunately, historians have tended to place less atten-

1 See, for example, Staffan Nilsson, "Hur X-strålarna nådde Dalarna och länslasarettet i Falun. Om röntgenteknikens spridning till landsorten kring sekelskiftet”, Nordisk Medi- 
tion on examining the reasons why those who needed medical assistance eventually turned to a doctor or midwife rather than the local folk healer or helpwoman to provide it.

One cannot talk about theories of diffusion without acknowledging the innovative work of Torsten Hägerstrand. ${ }^{2}$ Although his earliest studies are now more than 40 years old, reference to them still find their way into the bibliographies of those wishing to explore the mechanisms by which innovations spread from place to place and from person to person. Hägerstrand's most important contribution to questions such as these was the attention he placed on the role of informal communication between people. He believed that it was this, rather than state sponsored initiatives, that offered the most promising explanation for the diffusion of accepted practices. ${ }^{3}$ The major impediment to the widescale diffusion of innovations was not social inequality per se, but rather the fact that poverty often placed insurmountable obstacles in front of those who may have benefitted from information about a new method, product or behaviour.

A recent study of the diffusion of smallpox vaccination in southern Sweden during the early nineteenth century reveals that not all segments of the population were equally receptive to this innovation even though there was no financial cost attached to it. Martin Dribe and Paul Nystedt argue that it was not the wealth or level of education enjoyed by those most likely to vaccinate their children, but rather the greater access to information that the wealthy and educated enjoyed as a result of their privileged social and economic position. ${ }^{4}$ Anders Brändström, Sören Edvinsson, and John Rogers make a similar argument and conclude that the first women to employ a midwife typically came from the upper classes while those whose husbands were small farmers or unskilled workers were more likely to be among the 'laggards'.

The more recent work of Everett Rogers reaffirms Hägerstrand's conclusions regarding the importance of informal conversations but recognises that people do not always respond to common information in the same way or for the same

cinhistorisk Arsbok, (1994), 123-131. Of course this is only one of many such works that emphasise the role of individual physicians.

2 T. Hägerstrand, Innovation Diffusion as a Spatial Process. Trans. A. Pred. (Chicago: University of Chicago Press, 1967).

3 T. Hägerstrand, Innovation Diffusion as a Spatial Process. Trans. A. Pred. (Chicago: University of Chicago Press, 1967), pp. 77, 164.

4 Martin Dribe and Paul Nystedt, "Information, Trust and the Diffusion of Smallpox Vaccination: the Case of Scania in Sweden, 1802-1835”, Scandinavian Economic History Review, 51 (2003), 9-29.

5 Anders Brändström, Sören Edvinsson, John Rogers, "Did Midwives Make a Difference? A Study of Infant Mortality in Nineteenth-Century Sweden”, Paper presented at the European Association for the History of Medicine and Health conference, Oslo, September 37, 2003. 
reasons. He reminds us that the diffusion of innovation 'is essentially a social process in which subjectively perceived information about a new idea is communicated. ${ }^{6}$ For Rogers, the pace at which an individual accepts an innovation is determined by asking whether it offers some sort of advantage for the person (relative advantage), how closely it conforms to existing values (compatibility), how difficult it will be to adopt (complexity), whether it is possible to adopt it on a 'trial basis' (trialability), and finally, will it be possible to observe the effects of it (observability). ${ }^{7}$ Those innovations that promise the most advantage, entail no major cultural break, are relatively easy to adopt, provide the opportunity to revert back to previous practices, and offer clear and observable proof of their value are the most likely to be accepted quickly.

Obviously Rogers does not discount the power of government agencies to enforce new modes of behaviour or the power of science to provide irrefutable proof of the benefits of a new innovation. However, he is not convinced that they alone are sufficient to change behaviour. Although people may be aware of, and indeed impressed by scientific claims, 'most people depend mainly upon a subjective evaluation of an innovation that is conveyed to them from other individuals like themselves who have previously adopted the innovation. ${ }^{8}$

There can be no doubt that local communication networks were essential to ensuring the success of state sponsored medical initiatives. For this reason it is imperative that we identify those characteristics of interpersonal communication that either impeded or encouraged both the introduction of new ideas, and their wider acceptance within the community at large. Dribe and Nystedt emphasise how important it was for a sense of trust to exist between those seeking to implement a new technology and the potential recipients of it. ${ }^{9}$ Obviously it is difficult to identify the precise mechanism through which a trusting relationship is formed and then create an accurate measurement of it. None the less, the argument that Dribe and Nystedt present adds an important dimension to our understanding of how academic medicine diffused through society. Their work combines, rather than separates, the supply and demand driven models that attribute the gradual expansion of medical influence as the result of either a greater number of medical practitioners and institutions, or rising popular demand for such services. Instead, they suggest how the medical worlds of trained practitioners and that of largely isolated rural inhabitants may have been bridged. It does so by demonstrating how the combination of 'vertical trust' between medical practitioners and their patients, and 'horizontal trust' among

6 Everett Rogers, Diffusion of Innovations. 4th ed. (Toronto: Free Press, 1995), p. xvii.

7 Rogers, Diffusion of Innovations, pp. 15-16.

8 Rogers, Diffusion of Innovations, p.18.

9 Dribe and Nystedt, "Information, Trust and the Diffusion of Smallpox Vaccination”, 14-16. 
the different recipients of new innovations, in this case smallpox vaccination, allowed it to extend beyond the small group of 'innovators' to the larger group of 'laggards'.

Undoubtedly there were tremendous hurdles that $19^{\text {th }}$-century medical practitioners had to surmount in their efforts to introduce new methods and personnel into the more isolated parts of the country. Not only did they need to overcome perceived and actual socioeconomic differences between themselves and their patients, they also needed to convince the population of the advantages of their new methods. ${ }^{10}$

Sources available here do not permit a comprehensive understanding of the dynamics of historical village relationships or enable us to determine accurately the levels of trust that existed between individuals. The best we can hope to achieve is to identify those characteristics that may have acted as impediments to it. Some diffusion studies suggest that younger people are more likely to accept new ideas than are those who are somewhat older. ${ }^{11}$ Therefore, the level of success that these practitioners achieved may have been somewhat dependent upon the average age of their clientele. While it might be true that some younger women may have been more inclined to call a midwife if she was approximately the same age, others might have perceived her youth as proof of her inexperience. In such an environment the age and assumed experience possessed by an older midwife would have accelerated the diffusion of academic medicine rather than acted as a brake upon it. It is also possible that a midwife's ability to earn the trust of the women in her parish may also have been a function of the length of time she had lived in the parish. For example, people seem more likely to entrust their health to a physician who has lived in the area for 5-10 years rather than a new arrival even if the latter might be more qualified. ${ }^{12}$

Diffusion theorists and medical historians continue to debate the relationship between the presence of major 'crises' and the level of acceptance of new ideas. On the one hand, Grethe Banggaard suggests that a large outbreak of smallpox in southern Sweden in the early 1800s may have contributed to the fairly rapid and widespread acceptance of vaccination well before the state made it compul-

10 E. Rogers, Diffusion of Innovations, pp. 15-16, 332-4.

11 See for example, S. Svensson, "Bygd och yttervärld. Studier över förhållande mellan nyheter och tradition”, Nord. Museets Handlingar, 15 (1942). Hägerstrand, however, argues that knowing the age of individuals who adopted and refused to adopt innovations is unlikely to explain any pattern that might appear as people of various ages are generally randomly distributed through a region. Hägerstrand, Innovation, p. 150.

12 James Coleman, Elihu Katz, and Herbert Menzel, Medical Innovation: a diffusion study (Indianapolis, 1966), pp. 150-1. 
sory. ${ }^{13}$ On the other hand, other studies suggest that any surge in acceptance of new technologies during an epidemic would be short-lived, and that the rate of diffusion would return to expected levels not long after the crisis had passed. ${ }^{14}$

\section{The Sundsvall Region}

The 12 parishes of the Sundsvall region of Sweden contain a total area of approximately 2,600 square kilometres approximately 500 kilometres north of Stockholm. From the 1870 s to the early $20^{\text {th }}$ century this region was one of the world's largest lumber producing areas and many of its parishes were at the forefront of this rapid industrialisation. However, other parishes remained almost entirely dependent upon agriculture and were largely insulated from the economic and demographic boom occurring along the coast. By the end of the $19^{\text {th }}$ century the town of Sundsvall could boast of having 8 doctors - five more than in 1870, but there were still only two rural physicians for a population of more than 50,000 scattered throughout the various parishes. ${ }^{15}$ It was left to midwives to fill this medical vacuum.

\section{Sources}

This study examines midwives' daybooks to identify the extent to which academic medicine infiltrated two rural parishes of the Sundsvall region. ${ }^{16}$ These daybooks offer a valuable insight into the lives of these women by enabling us

13 Grethe Banggaard, "Sygdom och sundhed: offentlige indgreb och deres virkninger i Sydsverige ca. 1750-1894”, Lund Papers in Economic History, 76 (2002) cited in Dribe and Nystedt, "Information, Trust and the Diffusion of Smallpox Vaccination”, 22.

14 H. Earl Pemberton, "The Effect of a Social Crisis on the Curve of Diffusion", American Sociological Review, 2 (1937), 55; A.J. Mercer, "Smallpox and Epidemiological Demographic Change in Europe: the role of vaccination”, Population Studies, 39 (1985), 3034. One of the reasons for the lack of support for vaccination in Stockholm in 1874 was that the disease had been absent for several years prior to the epidemic. M. Clark-Nelson and J. Rogers, "The Right to Die? Anti-Vaccination Activity and the 1874 Smallpox Epidemic in Stockholm”, Social History of Medicine, 5 (1992), 370, 388.

15 Anders Brändström and Sören Edvinsson, "Folkhälsans utveckling - tiden efter 1870,” in L-G. Tedebrand ed. Sundsvalls Historia, vol. 2 (Sundsvall: Stadshistoriska Kommittéen, 1997), p. 190. The population of the rural parishes is based on files obtained from the Demographic Data Base (DDB) in Umeå, Sweden.

16 An earlier study used computerised parish registers to calculate mortality rates from direct obstetric deaths and assessed the role that midwives may have played in bringing it about. Stephan Curtis, "Midwives and the Role in the Reduction of Direct Obstetric Deaths during the late Nineteenth Century: the Sundsvall Region of Sweden (1860-1890)", Medical History, 49 (2005), 321-350. 
to follow their movements through their parishes. We can see how frequently they attended births in each of the far-flung villages and remote farms they visited, learn something about the women they helped, and any problems that may have arisen during or immediately after the births.

Of particular interest here are the comprehensive and complete run of daybooks from the parish midwives in the two inland parishes of Indal and Tuna from 1882 to 1890 . Unlike frequently the case elsewhere, these two parishes each had only one parish midwife which means that we can be relatively certain that all births attended by a midwife are recorded in the books available. Finally, in both cases the same midwife fulfilled her duties throughout the entire period being studied. In the parish of Indal, Maria Liljeqvist tended to the needs of approximately 550 women between the ages of 15 and 45 who lived there. ${ }^{17}$ The second set of daybooks comes from Elisabeth Holmgren, the parish midwife in Tuna, who was responsible for providing assistance to the 700 women in the same age group. ${ }^{18}$ These two women combined to attend a total of almost 850 births during this period. ${ }^{19}$

In addition to the daybooks from these two midwives, three other sources contributed to this study. Computerised parish records constructed by the Demographic Data Base (DDB) in Umeå, Sweden provide the raw data needed to identify birth and death rates, and provide information about the occupations and age structures of the population. Another valuable source is the DDB's internet database Indiko which provides additional information about specific individuals. Finally, the annual reports that physicians submitted to authorities in Stockholm serve as comprehensive medical topographies. Not only do they provide general statements about the level of health among the population, but they also shed light on the public's attitudes towards physicians and academic medicine in general.

\section{The Role of the State and the Supply of Medical Practitioners}

Already by the 1820s the Swedish government had launched measures designed to increase the likelihood that academic medicine would have a sound foundation in rural parishes. The creation of parish councils was a first step towards this goal. Their responsibilities included making the population aware of the

17 DDB files. It is generally accepted that a woman's fertile period is between 15-45 years of age.

18 These figures include only those who appear in the parish registers and do not take into account the large number of migrants travelling through these parishes to find work in the coastal sawmills or returning from them in the late autumn when the mills closed for the year.

19 Liljeqvist attended 512 and Homgren assisted with 335 births. 
consequences of their unhealthy lifestyles and the dangers of consulting quacks rather than licensed physicians. The government also charged them with ensuring that infants and children were not neglected. ${ }^{20}$ The preamble to legislation passed in 1822 reinforced the government's commitment to ensuring the health of its citizens regardless of where they lived by comprehensively describing the duties and responsibilities of all provincial physicians. ${ }^{21}$ By mid-century these measures had begun to be felt throughout the country and various pieces of legislation, of which the Public Health Act of 1874 was only the most prominent example, attested to the sincerity of this effort. Despite these best of intentions, traditional methods and cures remained well entrenched in the countryside and rural opposition to the intrusion of academic medicine ensured that the battle for local minds would be a long and difficult one. For example, the nineteenthcentury Swedish government was committed to providing the country with an army of well-trained midwives but it could not always convince the public to use them. It appears that even women living in parishes only somewhat distant from urban centres were reluctant to abandon their help-women and other unlicensed providers of medicine.

In addition to enacting various pieces of legislation the government did what it could to increase the number and skills of medical practitioners. Unfortunately, few could be enticed to the northern and remote parts of the country. ${ }^{22} \mathrm{~A}$ re-organisation of medical education and the creation of a new institution (Karolinska Institutet) charged with the training of physicians proved the state's commitment to increasing the number of skilled doctors. In 1805 there were only 281 people who had received medical training and of those only 52 were skilled both in medicine and surgery. By 1850 there were 463 doctors and almost 400 of them had both medical and surgical knowledge. ${ }^{23}$

By the late $19^{\text {th }}$ century many of the state's initiatives had paid off but it still had much to do especially outside the more populated areas in the south. Official statistics from 1861 reveal that there were a total of 452 physicians in all of Sweden, or one for every 8,500 people. In the province of Västernorrland the ratio was $1: 10,600$. By 1881 the total number of physicians in the country had risen to almost 570 and there was now one doctor for every 8,100 people. While this gradual improvement at the national level may have seemed encouraging enough to medical officials in Stockholm, the situation in Västernorrland was

20 The text of this legislation can be found in H. Wistrad, Författningar angående Medicinal-Väsendet i Sverige (Stockholm, 1860), p. 381.

21 “Kungl. Instruktion, d. 13 Juni 1822, för provincial-läkarne i riket”, in H. Wistrad, Författningar, pp. 213-224.

22 Henrik Sandblad, Världens nordligaste Läkare 1750-1810 (Stockholm, 1979), pp. 19-28,

23 Hilding Bergstrand, "Läkarekåren och Provinsialläkareväsendet," in Wolfram Kock ed. Medicinalväsendet i Sverige 1813-1962 (Stockholm, 1963), pp. 109-113. 
actually worsening. Each physician in that province was, by 1881, now responsible for more than 11,400 people. ${ }^{24}$

The number of provincial physicians i.e. those responsible for rural inhabitants rather than urban dwellers, paints an even more telling picture of the shortage of physicians working in the rural parishes of northern Sweden. In Västernorrland there was one of these medical practitioners for every 16,700 rural inhabitants in 1861. Twenty years later there had been no increase to the seven provincial physicians and this ratio had worsened to $1: 24,500$. A decade later the situation had worsened yet again as there was one of these physicians for every 30,300 people. $^{25}$ The point here is to reiterate how unlikely it would have been for most people living in small isolated villages to have ever encountered a provincial doctor unless he had been specifically summoned either by a midwife to assist with a particularly difficult birth, or by a parish council confronting an epidemic.

The shortage of trained physicians meant that government officials relied almost entirely on midwives to improve the population's health. The result was a comprehensive strategy designed to achieve three objectives: prevent unlicensed women from attending births; increase the number of formally, welltrained midwives; and make these women an integral part of the medical landscape. Already in 1819 all women who wanted to work as a midwife were required to be trained unless no licensed midwife was available. Legislation introduced that year also made it illegal for women to use the services of unlicensed 'Jordgummor' if there was a trained midwife in the parish. ${ }^{26}$ At least that was what the legislation prescribed but what happened in the field was frequently another matter entirely. As late as the early $20^{\text {th }}$ century a very small minority of parishes simply refused to replace untrained midwives with ones who had received their licence. ${ }^{27}$

Figure 1 compares the ratio of females to midwives for Sweden, the province of Västernorrland, and the Sundsvall region to illustrate the government's success in gradually increasing the supply of these medical practitioners. The provision of these women in this group of parishes compared quite favourably both to the country as a whole and to the province with the exception of the early 1870 s

24 Bidrag till Sveriges Officiella Statistik (BiSoS) Series K. It is also worth noting that the national figures paint a particularly optimistic image because they include the 111 doctors practicing in Stockholm where, in 1880 the ratio of doctors to population was 1:1,600.

25 BiSoS K.

26 Riksarkivet. Årstrycket 1819, Nr. 18. "Reglementet för barnmorskor”.

27 Christina Romlid, Makt, Motstånd och förändring: Vårdens historia speglad genom det svenska barnmorskeväsendet 1663-1908 (Stockholm, 1998), pp. 197-204, 291; Irvine Loudon, Death in Childbirth: an international study of maternal care and maternal mortality, 1800-1950 (Oxford, 1992), pp. 408, Ulf Högberg, "The Decline in Maternal Mortality in Sweden: the role of community midwifery”, American Journal of Public Health, 94 (2004), 1312-1320. 
Figure 1. Ratios of Females to Midwives in Sweden, Västernorrland, and the Sundsvall Region (1861-90),

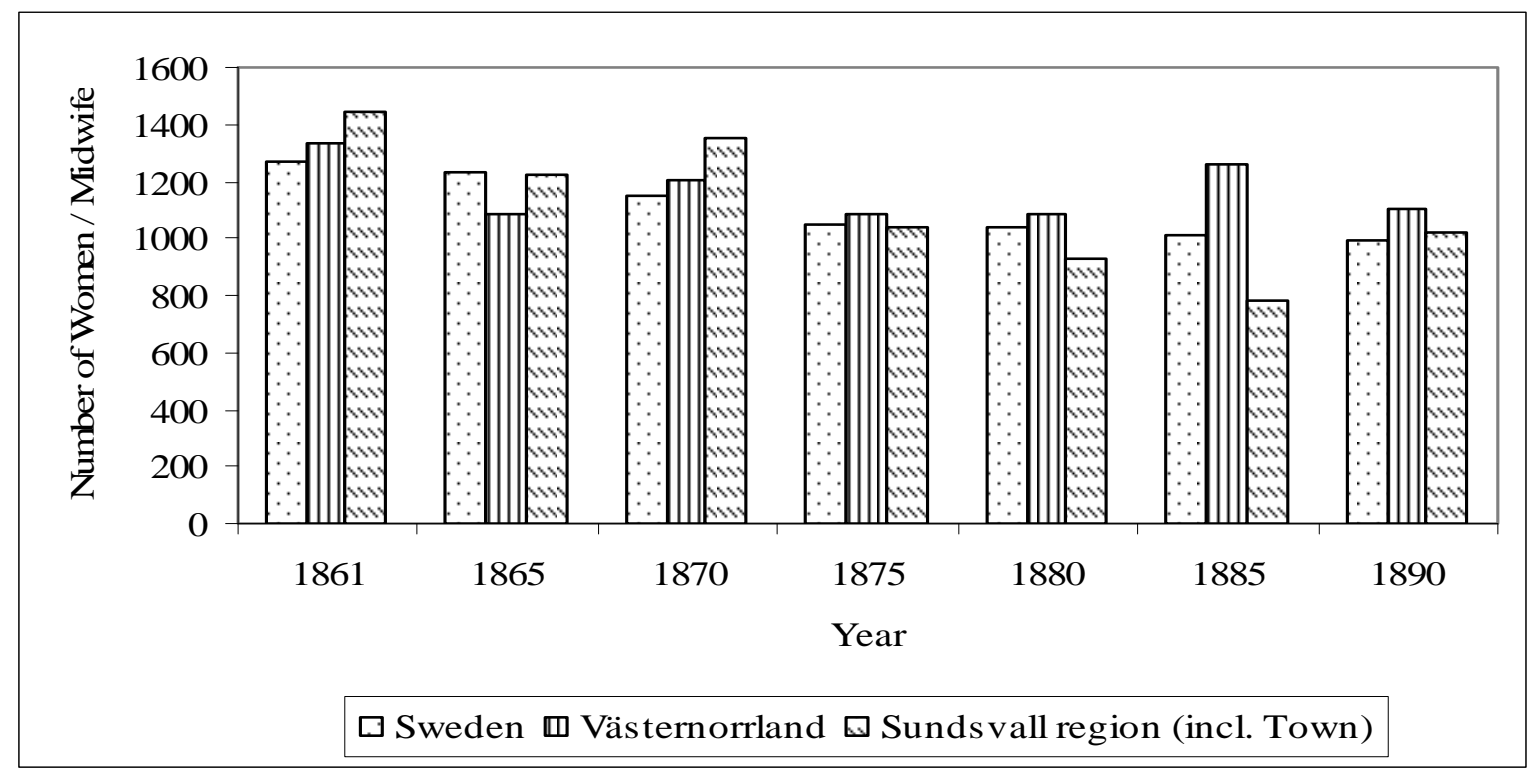

Sources: DDB files; RA. Sundhets Collegium and Medicinal Styrelsen, Series E5A (Årsberättelser från Provincialläkare). Reports from Sundsvall and, after 1870, Wifstavarf District Physicians.

when rapid economic and demographic growth in the area clearly undermined the state's efforts to provide an adequate number of midwives.

The second objective was to ensure an adequate supply of skilled midwives and here, too, the government was largely successful. Midwives' training became increasingly more comprehensive and included a wide array of nonobstetrical instruction. It was first doubled from 3 to 6 months and part of this education entailed the treatment of childhood diseases. ${ }^{28}$ The government undertook various strategies to increase the number of midwives such as reducing the cost of their education and offering free training to a limited number of rural women who otherwise could not pay for their education. In 1829 midwives were granted the right to use sharp instruments provided they first complete an additional 3 months of training, and if it was impossible for a physician to be present at the birth. ${ }^{29}$ The state introduced additional legislation in 1856 regarding the education and duties of midwives that clearly defined the training that they would be required to complete, their responsibilities and the conditions under which they could use instruments or provide medications. ${ }^{30} \mathrm{In}$ 1863 the government decreed that all midwives would be required to receive

28 See, for example, P.G. Cederschjöld, Handbok för Barnmorskor (Stockholm, 1822)

29 Romlid, Makt, Motstånd och förändring, p. 292.

30 This legislation and subsequent amendments can be found in $\mathrm{H}$. Wistrad, Författningar, pp. 552-560. 
training in the use of instruments. ${ }^{31}$ Government officials tackled the problem of puerperal fever on 13 June, 1881 by sending a circular to all midwives instructing them to follow all necessary steps to provide as clean a birthing environment as possible. ${ }^{32}$

The government expected these women to do far more than simply attend births. For example, they were taught how to combat many childhood diseases and would have been the primary source of such information among those who lived outside the towns where doctors were most likely to be found. Their most important role, however, extended far beyond the treatment of diseases or assisting at births. They, and members of the clergy, were also expected to change the public's behaviours and attitude toward modern medicine. ${ }^{33}$ This required them to participate in a comprehensive restructuring of how people perceived physicians and midwives and the potential value of the new medicine they brought with them.

\section{Midwives in the Parishes of Indal and Tuna}

Between 1882 and 1890, Maria Liljeqvist and Elisabeth Holmgren attended approximately $65 \%$ of all births that occurred in their parishes of Indal and Tuna. Until 1887, Liljeqvist attended almost $10 \%$ more births per year than did Holmgren in Tuna. ${ }^{34}$ It seems that this was well below average for the region as a whole. ${ }^{35}$ Sundsvall's district physician, Dr Söderbaum, reported that for most of the parishes under his supervision midwives attended 65\% of all births in 1884 and more than $80 \%$ of them by $1890 .^{36}$ This was well above the national average

31 A. Kullberg, Författningar m.m. angående Medicinialväsendet i Sverige omfattande tiden från och med år 1860 till och med år 1876 (Stockholm, 1877), p. 99.

32 Almost all daybooks from the Sundsvall region for this period include a copy of this legislation to their daybooks for easy reference. Härnösand Landsarkiv.(hereafter H-sand) Series D III “Första Provincialläkaren i Vasternorrlands län. Barnmorskors dagböcker "Kongl. Medicialstyrelsens cirkulär till barnmorskorna i riket, angående försigtighetsmått, som böra af dem iakttagas till förekommande utfärdadt den 13 Juni 1881.”

33 Romlid, Makt, Motstånd och förändring, p. 291-4.

34 However, these figures are deceptive especially by the late 1880s when Holmgren attended many more births per year than did Liljeqvist. The number of births attended is found in H-sand, Förste Provinsialläkarens i Västernorrlands län, "Barnmorskors dagbocker “- Tuna and Indal Series D III:I. The total number of births in these parishes is supplied by the 'Birth file' constructed by the DDB.

35 H-sand, Förste Provinsialläkarens i Västernorrlands län, "Barnmorskors dagböcker - Indal and Tuna” Series D III:I. DDB files provide the total number of births in this parish.

36 RA. Medicinal Styrelsen. Series E5A, 'Årsberättelser från provinsialläkare' XIV. Report \#114 from Dr. Söderbaum in Sundsvall. He reported that there had been a total of 450 births in the parishes for which he was responsible. 
of approximately $70 \%$ of all home deliveries that midwives attended in $1890 .{ }^{37}$ Obviously women in much of the region had, by the 1890s, almost entirely abandoned help-women and entrusted their own health and that of their newborns to the skilled hands of midwives. See Table 1.

Table 1. Total Number of Births and Births Attended in Indal and Tuna Parishes 1881-90.

\begin{tabular}{|c|c|c|c|c|c|c|c|c|c|c|}
\hline & 1882 & 1883 & 1884 & 1885 & 1886 & 1887 & 1888 & 1889 & 1890 & Total \\
\hline Indal(total births) & 59 & 91 & 85 & 73 & 96 & 80 & 72 & 91 & 70 & 717 \\
\hline $\begin{array}{l}\text { midwife present } \\
\text { Indal \% births }\end{array}$ & 39 & 56 & 59 & 48 & 66 & 53 & 60 & 65 & 39 & 485 \\
\hline attended & 66.1 & 61.5 & 69.4 & 65.8 & 68.8 & 66.3 & 83.3 & 71.4 & 55.7 & 67.6 \\
\hline Tuna(total births) & 101 & 86 & 91 & 86 & 116 & 99 & 130 & 110 & 143 & 962 \\
\hline $\begin{array}{l}\text { midwife present } \\
\text { Tuna \% births }\end{array}$ & 57 & 45 & 54 & 45 & 69 & 67 & 84 & 76 & 97 & 594 \\
\hline attended & 56.4 & 52.3 & 59.3 & 52.3 & 59.5 & 67.7 & 64.6 & 69.1 & 67.8 & 61.7 \\
\hline Total births & 160 & 177 & 176 & 159 & 212 & 179 & 202 & 201 & 213 & 1679 \\
\hline $\begin{array}{l}\text { midwife present } \\
\text { Total \% births }\end{array}$ & 96 & 101 & 113 & 93 & 135 & 120 & 144 & 141 & 136 & 1079 \\
\hline attended & 60.0 & 57.1 & 64.2 & 58.5 & 63.7 & 67.0 & 71.3 & 70.1 & 63.8 & 64.3 \\
\hline
\end{tabular}

Sources: DDB files and Midwives’ Daybooks, (Förste Provinsialläkarens i Västernorrlands län, ‘Barnmorskors Dagböcker, Series D III:1 (Tuna and Indal Parishes).

By all appearances these two women shared very similar life-histories and they would not have been considered very much different from the population at large. Liljeqvist was born in Kalmar province in the south of Sweden and was 32 years old when she arrived in Indal with her husband and two sons in $1878 .{ }^{38}$ Her husband, a farmer and carpenter, had been born in the province of Östergötland. ${ }^{39}$ Within a year of their arrival they had another son but he died within two weeks of being born and it is possible that this personal tragedy prompted Liljeqvist to become a midwife two years later in 1881. Holmgren and her husband also were not native to the Sundsvall region. She had been born in Kopparberg province but by the time she began her career as a midwife in 1865 she had already been in Tuna for five years. ${ }^{40}$ As was the husband of Lileqvist, her husband was also a native of Östergötland and also appears in the parish records as a carpenter. ${ }^{41}$ Both women had children of their own although

37 RA. Medicinal Styrelsen. Series E5A, “Årsberättelser från provinsialläkare”, XXIV. Report \#248 from Dr. Söderbaum in Sundsvall. U. Högberg, S. Wall, and G. Broström, "The Impact of Early Medical Technology on Maternal Mortality in Late 19th-Century Sweden”, Int. J. Gynecol. Obstet., 24 (1986), 255.

38 Indiko database id \# 846002666.

39 Indiko database id \# 851002899.

40 Indiko database id \# 823001950.

41 Indiko database id \# 823002013. 
Holmgren's eldest son died in 1878. Despite the fact that these two midwives had not grown up in the Sundsvall region, they had enough in common with the local population that they probably would have no difficulty fitting into local society. Certainly there is no reason to believe that either woman's social status or residence history gave her some advantage over the other when trying to garner the trust of local women although it is true that by 1882 Holmgren had resided in the region far longer than had Liljeqvist and at 59 years of age was 23 years older.

It appears that those living in Indal enjoyed, on the whole, a somewhat more secure livelihood than inhabitants of Tuna. Table 2 illustrates the occupational structure of all people over the age of 15 in the two parishes of Indal and Tuna in 1885. The percentage of farmers was almost identical in the two parishes but the percentage of crofters in Indal was almost three times higher than in Tuna. This suggests at least some degree of security in the event of poor harvests or particularly harsh winters. No such insurance existed for the labourers and daylabourers who accounted for a higher percentage of the total population in Tuna than in Indal. See Table 2.

Table 2. Selected Occupations at Death for those Aged 15 Years or Older (1885).

\begin{tabular}{lll}
\hline Occupation & Indal & Tuna \\
\hline Unknown (n) & 402 & 412 \\
$\%$ & $22.30 \%$ & $21.51 \%$ \\
Farmer (n) & 389 & 407 \\
$\%$ & $21.58 \%$ & $21.25 \%$ \\
Crofter (n) & 402 & 153 \\
$\%$ & $22.30 \%$ & $7.99 \%$ \\
Farm worker (n) & 47 & 80 \\
$\%$ & $2.61 \%$ & $4.18 \%$ \\
Maid (n) & 122 & 185 \\
$\%$ & $6.77 \%$ & $9.66 \%$ \\
Labourer (n) & 256 & 420 \\
$\%$ & $14.20 \%$ & $21.93 \%$ \\
\hline Total (n) & 1803 & 1915 \\
\hline
\end{tabular}

Source: DDB Files.

The occupational structure among women at the birth of their child for the two parishes is shown in Table 3 and largely confirms the pattern shown above although the dependence upon day labour and the very few cotters in Tuna parish is even more apparent. See Table 3. 
Table 3. Mothers Occupations at birth of their Child in Indal and Tuna (188290).

\begin{tabular}{llllll}
\hline Indal & $\mathbf{N}$ & $\mathbf{\%}$ & Tuna & $\mathbf{N}$ & $\mathbf{\%}$ \\
\hline Farmer & 214 & 29.8 & Farmer & 257 & 26.7 \\
Crofter & 218 & 30.4 & Crofter & 55 & 5.7 \\
Maid & 33 & 4.6 & Maid & 53 & 5.5 \\
Labourer & 179 & 25.0 & Labourer & 410 & 42.6 \\
Total & 644 & 89.8 & Total & 775 & 80.5 \\
\hline Total all records & 717 & & Total all records & 962 & \\
\hline
\end{tabular}

Source: DDB Files.

Although not too much can be made from these Tables, they do suggest that the average inhabitant of Indal was somewhat better off than those in Tuna and, perhaps, this relative wealth made the population of Indal more willing to accept new ideas. The presumed ability of most people to pay a financial penalty for neglecting to have a midwife deliver their children might explain the decision taken by Indal's parish council to impose a fine on women who chose to employ the services of a help-woman. ${ }^{42}$

The salary the midwives received from their respective parishes also suggests that the economy of Indal was healthier than that of Tuna. In 1881, Holmgren received 400 kronor from Tuna parish. Eight years later the total of her salary and other income had increased only to approximately 410 kronor. In contrast, Liljeqvist's salary in Indal parish had improved considerably during this period from 450 to almost 550 kronor although her daybooks reveal that she was attending far fewer births than was Holmgren. ${ }^{43}$

It was not without good reason that authorities encouraged women to take advantage of the services that midwives offered and penalised those that did not heed this advice. Swedish midwives were among the most skilled in nineteenthcentury Europe and the relatively low maternal and infant mortality rates attest to their abilities. Ulf Högberg has conducted the most thorough investigation of maternal mortality in Sweden and argues convincingly that the midwives' knowledge of antisepsis in the early 1880s was directly responsible for reducing the number of women who died as a result of childbirth. ${ }^{44}$ By the late nineteenth

42 On 12 December 1880, for example, in response to learning that Liljeqvist had not been called to assist with several births, the parish council declared that the new mothers would each be required to pay two kronor to the council which would then forward it to her. Sundsvall. Medelpadsarkivet, Series A1:2 Indahls Kommun Kommunalstämma protokoll (12 December, 1880).

43 Med. Styr. E5A, “Årsberättelser från Provincialläkare i Sundsvall”, Vols. 8 (1881), and 24 (1889).

44 U. Högberg, S. Wall, and G. Broström, “The Impact of Early Medical Technology, p. 254. See also Irvine Loudon, Death in Childbirth, p. 412. Idem., "Maternal Mortality in the 
century maternal mortality rates in Sweden were lower than those found elsewhere in Europe. ${ }^{45}$ Table 4 illustrates midwives' overall success in reducing the rate of direct obstetric deaths i.e. those that were most probably an immediate consequence of childbirth from the 1870s onward in Sweden and the Sundsvall region. The sole exception to this largely secular decline was the increase in the Sundsvall region during the early $1880 \mathrm{~s}^{46}$ In those parishes a total of only slightly more than 220 women died as a result of complications at birth during the entire period from 1860 to 1890 . This is not to discount these deaths as irrelevant or suggest that they were anything but devastating to their families. The point is that although women did die from childbirth, such events were uncommon enough that most people would probably have had no knowledge of them unless the deceased lived nearby.

Table 4. Mortality Rate from Direct Obstetric Causes / 100,000 Live Births (1856-1890).

\begin{tabular}{llllllll}
\hline & $\mathbf{1 8 5 6 -}$ & $\mathbf{1 8 6 1 -}$ & $\mathbf{1 8 6 6 -}$ & $\mathbf{1 8 7 1 -}$ & $\mathbf{1 8 7 6}-$ & $\mathbf{1 8 8 1}-$ & $\mathbf{1 8 8 6}-$ \\
& $\mathbf{1 8 6 0}$ & $\mathbf{1 8 6 5}$ & $\mathbf{1 8 7 0}$ & $\mathbf{1 8 7 5}$ & $\mathbf{1 8 8 0}$ & $\mathbf{1 8 8 5}$ & $\mathbf{1 8 9 0}$ \\
\hline Sundsvall Region & 460.0 & 599.0 & 530.0 & 646.0 & 355.0 & 438.0 & 377.0 \\
Sweden & 450.0 & 550.0 & 540.0 & 620.0 & 520.0 & 400.0 & 350.0 \\
\hline
\end{tabular}

Source: DDB files.

The reduction of infant mortality during the course of the nineteenth century also demonstrates the expertise that midwives had achieved. Here, too, Sweden had a pronounced advantage over other European countries. Within the Sundsvall region, the infant mortality rate peaked in 1875 due largely to the tremendous population increase and concomitant worsening of living conditions that characterised the most industrialised parishes. In that year, the infant mortality rate for the entire region was almost 250/1,000 while that found in the industrial parishes of Skön and Alnö reached almost 300/1,000. Thereafter the regional infant mortality rate followed a largely secular decline until by 1890 it was less than 160/1,000. Infant mortality in both Indal and Tuna followed this general trend. In the former it declined from 139/1,000 in 1875 to approximately 102/1,000 in 1890 and Tuna parish witnessed a similar decline from 230/1,000 to $173 / 1,000$ during the same period. ${ }^{47}$

It is impossible to know whether women were aware that more and more infants were surviving their first year of life, and that the likelihood of surviving

past and its Relevance to Developing Countries Today”, American Journal of Clinical Nutrition, 72 (2000), (suppl):241-6s.

45 See, I. Loudon, Death in Childbirth, pp. 542-553.

46 The very small number of women who died from such causes in individual parishes, let alone individual villages, makes the calculation of such rates at that level quite pointless.

47 DDB files 
childbirth also seemed to be improving. Residents in the town and its immediate hinterland may have been cognisant of such trends because local newspapers often included information about the town's mortality statistics but whether such information typically reached women living in the more distant parishes remains unclear. ${ }^{48}$ Although we should be cautious about attributing the rise of academic medicine solely to the real or imagined benefits it provided to the wider population, it is reasonable to assume that women would not have called upon a midwife unless they were convinced that she offered some advantage to them that a 'help-woman' did not.

Changes in the disease panorama and a perception that practitioners failed to protect the population or respond adequately when people became sick could certainly have undermined public faith in the abilities of doctors and midwives. Major epidemics of scarlet fever and diphtheria arrived for the first time in the Sundsvall region in the latter decades of the nineteenth century. Circumstantial evidence suggests that it was at times such as these that parents dropped their often well-justified reservations about seeking medical care from trained physicians. Their sheer desperation often resulted in doctors being called to treat extremely sick children. ${ }^{49}$ While one can hardly construe this as a raving endorsement of academic medicine, it at least suggests that it was now on the population's mental radar. Between 1860 and 1890, these two diseases alone accounted for at least 1,700 deaths among infants and children less than nine years of age. ${ }^{50}$ There are no accurate records revealing how many young children contracted but survived their encounter with these diseases but the number must have been several times that figure.

We should not be surprised if some parents blamed the doctor or parish midwife for the death of their or a neighbour's child. After all, these practitioners had received training in the treatment of childhood diseases and often took it upon themselves to discredit those who did not have formal training. It is somewhat surprising, then, that no such attack against physicians and midwives occurred. Between 1860 and 1885, there is no correlation between the number of children who died from these diseases in a particular village and the likelihood that a midwife would attend births in them. In Tuna parish, for example, nineteen children died from diphtheria and 8 of those deaths occurred in the village of Vivsta. However, Holmgren attended between $1 / 2$ and $3 / 4$ of all births that occurred

48 See, for example, the newspaper Sundsvalls-Posten \# 30, 24 February, 1890.

49 Stephan Curtis, "In-migration and Diphtheria Mortality among Children in the Sundsvall Region during the Epidemics of the 1880s", Journal of the History of Medicine and Allied Sciences 63 (2008), 23-64; Marie Clark Nelson. "The Year the Children Died: a study of the diphtheria epidemic in Råneå parish, Sweden”, in John Rogers ed. Death and the public spheres, (Uppsala, 1986), pp. 53-75.

50 DDB files. 
there. Similarly, diphtheria claimed the lives of 5 children in Rude but Holmgren attended more than $75 \%$ of all births in that village. There were fewer deaths from scarlet fever than from diphtheria with 3 of the 4 deaths during this period occurring in Hallsjö. Again, it seems that the people did not hold Holmgren in any way responsible and her reputation did not suffer as a result of these deaths.

\section{Practical Obstacles to Midwives’ Ability to Provide Medical Care}

It could not have been easy to be a midwife in rural Sweden and particularly not in parishes so far north of the capital. A harsh climate, poor roads, and slow communication all contributed to the hardships these women faced. An expanding economy brought more and more people to the region that increased midwives' workloads.

There appears to have been a gradual improvement in the ratio of women who would have been most likely to require birthing assistance to midwives between at least 1870 and 1890 for the region as a whole reveals. Unfortunately, some parishes continued to be underserved throughout this period. This was particularly true for the inland parishes of Indal and Tuna where 1,200 women between the ages of 15 and 45 were dependent upon the services of the two parish midwives. ${ }^{51}$ As might be expected, the situation in the coastal industrial parishes was considerably better with one midwife for every 400 women within this age group. $^{52}$ Table 5 compares the ratio of women to midwife in the various groups of parishes in the Sundsvall region, the town of Sundsvall itself, and the two parishes of Indal and Tuna.

Despite being somewhat insulated from the unprecedented population boom occurring along the coast, the total number of inhabitants living in the parishes for which Holmgren and Liljeqvist were responsible also rose during the second half of the nineteenth century. This was particularly true for Tuna parish which saw its total population increase from 2,100 in 1860 to 3,400 in 1890. This resulted in an additional 230 women between the ages of 15 and 45 being added to Holmgren's potential clientele. Indal witnessed a much more modest growth with only 400 more people being added to the parish records during this period. Of these new inhabitants, only 50 were likely to need Liljeqvist's assistance. This very gradual increase in the number of fertile women in Indal produced only a slight increase in the total number of births from an average of 65 per

51 These figures are for 1885 when there were 625 women in Tuna and 551 in Indal between 15 and 45 years of age. DDB files.

52 DDB files. 
year during the 1860 s to approximately 80 per year in the 1880s. These figures were only marginally lower than those for Tuna parish. ${ }^{53}$

Table 5. Ratio of women (15-45) to midwives.

\begin{tabular}{lccccccc}
\hline $\begin{array}{l}\text { Parish Location } \\
\text { and Economy }\end{array}$ & $\mathbf{1 8 6 0}$ & $\mathbf{1 8 6 5}$ & $\mathbf{1 8 7 0}$ & $\mathbf{1 8 7 5}$ & $\mathbf{1 8 8 0}$ & $\mathbf{1 8 8 5}$ & $\mathbf{1 8 9 0}$ \\
\hline Coastal Industrial & 355 & 491 & 514 & 402 & 398 & 448 & 356 \\
Coastal Diversified & 472 & 504 & 554 & 446 & 516 & 420 & 470 \\
Coastal Agricultural & 227 & 452 & 236 & 261 & 273 & 146 & 278 \\
Inland Diversified & 970 & 1006 & 1161 & 1270 & 655 & 664 & 707 \\
Inland Agricultural & 653 & 569 & 839 & 428 & 363 & 485 & 518 \\
Town of Sundsvall & 627 & 491 & 439 & 505 & 221 & 210 & 338 \\
\hline Total & 522 & 551 & 573 & 474 & 352 & 353 & 400 \\
Indal Parish & 499 & 495 & 492 & 517 & 539 & 551 & 548 \\
Tuna Parish & 493 & 540 & 585 & 693 & 646 & 625 & 733 \\
\hline
\end{tabular}

Source: Files constructed by the DDB, Umeå University. ${ }^{54}$

The most serious impediment to the spread and acceptance of academic medicine must have been the geographical distances that these women had to travel to fulfil their duties. In 1890 there were a total of 12 midwives working in the group of industrial parishes located along the coast. The total area of these parishes amounted to 225 square kilometres, or, expressed another way there was 1 midwife for every 19 square kilometres. In stark contrast to this relatively dense coverage were those parishes located in the interior where each midwife was responsible for an average of more than 300 square kilometres. ${ }^{55}$

Midwives in both parishes had greater success attending births in some villages than in others. One can generally see an inverse relationship between the percentage of births attended and distance the midwife would have needed to travel. Map 1 displays the location of the various villages in Indal parish and the percentage of births that Liljeqvist attended. For the parish as a whole, it was distance from her residence that largely dictated whether she would assist with

53 There were approximately 80 births per year in Tuna during the 1860s and slightly more than 100 per year during the 1880s. DDB files.

54 The coastal industrial parishes include the major parishes of Alnö, Skön, Njurunda, and Timrå. Hässjö is the sole coastal diversified parish, and Tynderö is the only coastal agricultural parish. The inland diversified group of parishes consist of Attmar and Tuna. Indal, Ljustorp, Sättna and Selånger belong to the inland agricultural group of parishes.

55 Included here are the 2 groups of inland parishes. The 'inland diversified' group included the parishes of Attmar and Tuna. The parishes of Indal-Liden, Ljustorp, Sättna and Selånger comprise the group designated as 'Inland agricultural'. Tuna parish had an area of 217 square kilometres and Indal was slightly larger and occupied an area of 309 square kilometres. 
the birth. ${ }^{56}$ She delivered $73 \%$ of all infants born within 2 kilometres of her home although this included 5 sets of twins. Between 2 and 5 kilometres from her home she only attended slightly more than one-half of all births. Although several of the villages in which births occurred were quite some distance from the major road running through the parish, this does not appear to have presented a significant obstacle to her. The most obvious exception is the village of Högsjö along the southern border of the parish where she managed to attend only 5 of the 36 births between 1882 and 1890 .

However, before we place too much emphasis on the relative isolation of a village as an explanation of why midwives were unlikely to be present at the majority of births, it is worth noting that only a kilometre away from Säter where Liljeqvist delivered only 13 of 34 infants was the village of Backen where she assisted with all 40 births. ${ }^{57}$ Both of these villages were similarly distant from the main artery running through the parish. There were also villages even closer to home where she had difficulties convincing local women to call upon her expertise. She attended only 2 of the 16 births in Prästbordet although it was just slightly more than 2 kilometres from where she lived. The fact that both of these births were to Olifvia Bergström further illustrates the degree to which she had failed to convince most local women of the benefits she could offer. ${ }^{58}$ Similarly, at Indals Såg, a mere 3 kilometres away from her home in Kårsta, Liljeqvist delivered only 1 of 50 infants. ${ }^{59}$ It is possible that the sawmill had its own midwife but there is no evidence to suggest this was the case. Although Liljeqvist seems to have been unable to garner the trust of those living in Prästbordet or at Indals Såg, she was much more successful in doing so in the village of Sunnås almost 15 kilometres away where she attended 13 of 22 births. ${ }^{60}$ See Map 1.

The distance that Holmgren in Tuna parish would have had to travel also largely explains whether she would be present at births. ${ }^{61}$ In fact distance from her home appears to have been even more important than in Indal as it is statistically significant beyond 5 kilometres. However, while it might be tempting to

56 Correlation is significant at the 0.05 level.

57 DDB files and Midwives daybooks

58 Why Bergström was the sole woman in the village to turn to Liljeqvist is unknown. She already had 6 children before the first recorded birth delivered by Liljeqvist in 1886 but the records do not reveal whether a midwife had attended them. What we do know is that she was born in the nearby parish of Selånger and arrived in Prästbordet in 1880. Her husband, a farmer, was from a parish approximately 90 kilometres north of Sundsvall and had lived in Indal since 1858.

59 Härnösand, Förste Provinsialläkarens i Västernorrlands län, "Barnmorskors dagböcker - Indal" Series D III:I.

60 This higher percentage of attended births in that village was not simply the result of mothers calling upon Liljeqvist to deliver more than one infant.

61 Correlation for the whole file is significant at the .01 level period. 
attribute this to the fact that by 1890 Holmgren was 67 years of age while Lileqvist in Indal was only 44 years old, there might also have been another explanation for her inability to attend more births in the easternmost villages of the parish.

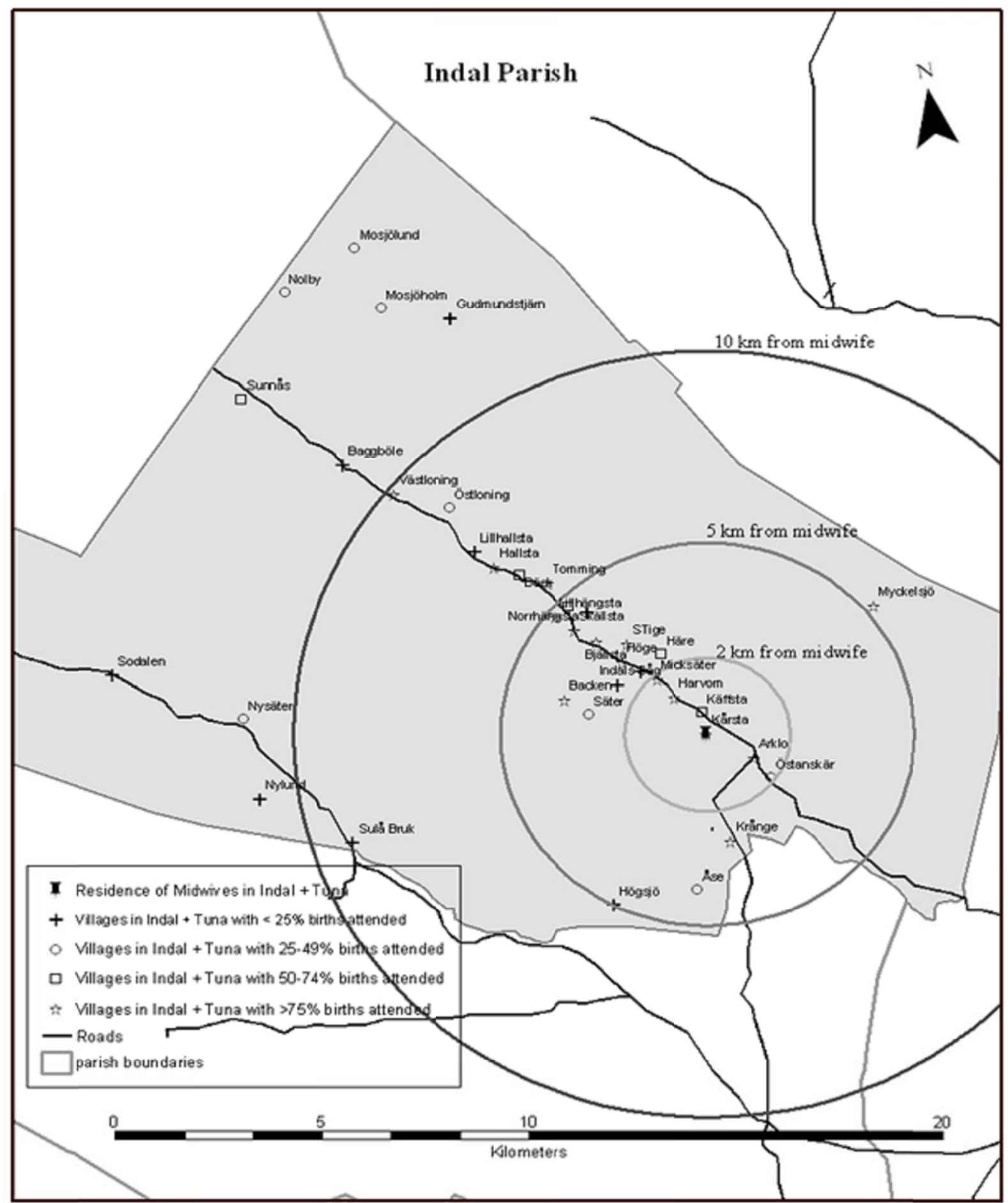

Holmgren attended $65 \%$ of all births that occurred within 2 kilometres of her home, and $75 \%$ of those that occurred between 2 and 5 kilometres from her residence. Only beyond that distance did the percentages of attended births decline 
markedly. She appears to have had a particularly hard time influencing the behaviour of women living in the cluster of 5 villages (Allsta, Borgen, Klingsta, Tunbyn, and Wii) located within 5 kilometres of one another in the easternmost part of the parish and all on major roads. See Map 2.

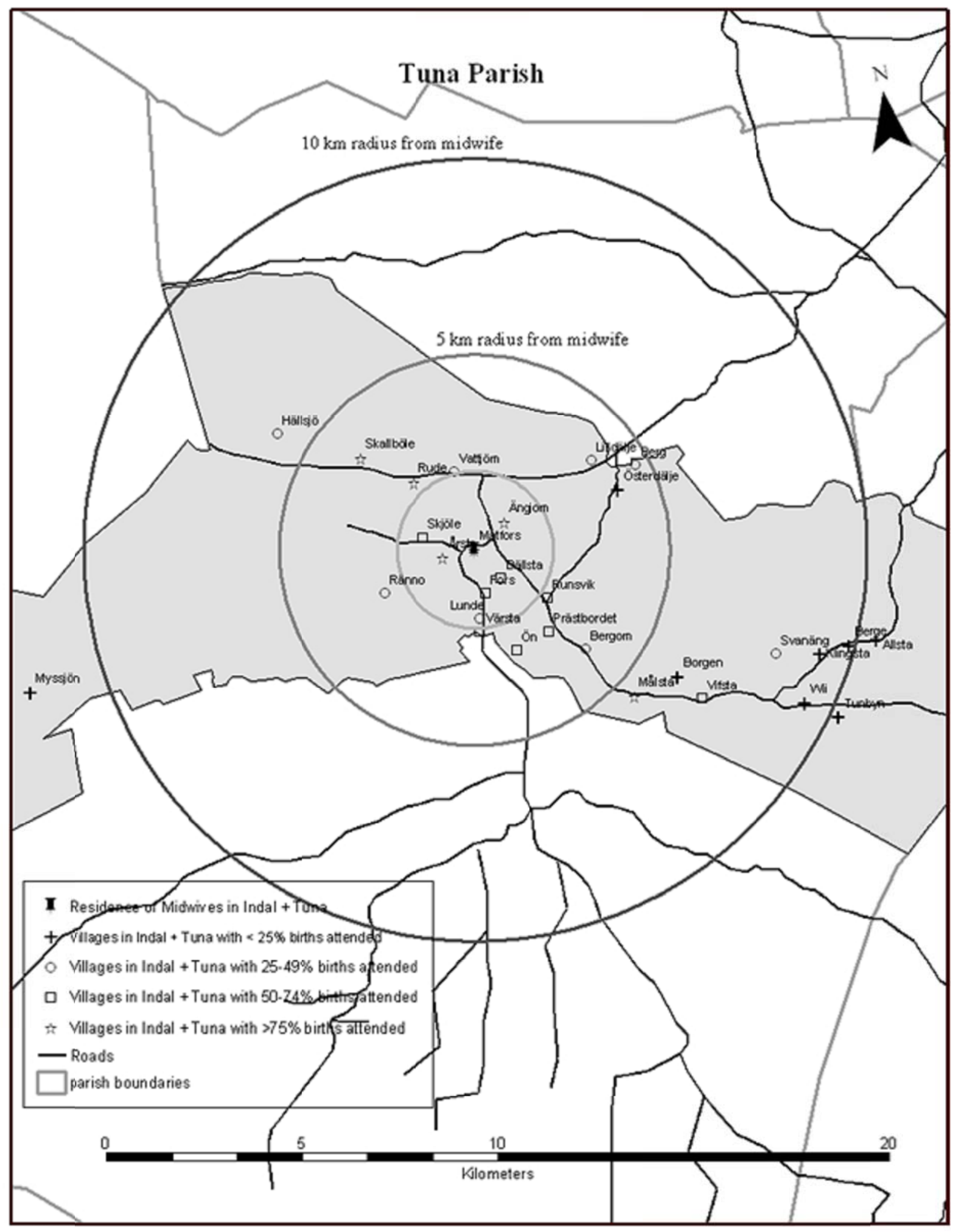


Nothing suggests that the women in these villages had any real reason to question Holmgren's expertise. According to her records, she had employed forceps only twice during the 23 births she had attended during her career and in both cases the infant survived. In fact only one infant had died of all the ones she delivered. There is, however, a disturbing pattern in the village of Tunbyn that does not appear in Holmgren's daybooks. Between 1880 and 1885, 8 infants died before they reached 2 months of age. ${ }^{62}$ This was far more than occurred elsewhere in this cluster of villages and may have at least caused some local residents to question her expertise.

The death of the 41-year old Brita Nordstrand, the only woman to have died as a result of childbirth in this group of villages, may have proven even more damaging to Holmgren's reputation. ${ }^{63}$ There is no way of knowing if this event caused people to question whether her presence at a birth minimised or increased the risk of a fatal outcome. Similarly we cannot be sure if such questions, if they arose, were widely articulated or simply remained lurking in the subconscious of local men and women. However, it does seem more than just coincidence that Holmgren attended such a small percentage of births in precisely those villages that had witnessed several deaths among very young infants and a very rare case of a mother dying during childbirth.

Nordstrand's death in 1882 was an exceptional case and the delivery of her still-born son made it an even more tragic one. Most of the villagers would have at least known of her through their relationships with her father. He and his father had been born in Allsta and both earned their livelihoods as jurists which would have brought them into contact with many of the local inhabitants. Brita's father began his career already in 1834 when he was twenty years of age. When he died in 1864, Brita was the sole remaining heir. ${ }^{64}$ In April 1865 she married the farmer Georg Hansson who had been born in Attmar but had moved to Allsta in late November the previous year. ${ }^{65}$ All this suggests that Brita was wellknown in the village and her death during childbirth was sure to have attracted a great deal of attention not just because of who she was, but also because of the nature of her death. Furthermore, villagers would know that her 6 surviving children were now motherless. We can never determine the degree to which the midwife was held responsible for the death of Brita and her son but it is not unlikely that whispers surrounded the whole affair and that Holmgren's reputation suffered as a result.

62 The cause of death for all of these infants is not given in the records.

63 Midwives database id \# 3482033. Indiko \# 839002056

64 Indiko \# 810001257. The duties of this group of professionals can be found in HISCO Historical International Standard Classification of Occupations (Leuven, 2002), p. 122.

65 Indiko \# 842002423. 


\section{Conclusion}

This study has gone some way to refuting the idea that by the late 1880s academic medicine was universally well entrenched in the rural parishes. There is no doubt that more and more women were using midwives to deliver their infants than had been the case earlier in the century but pockets of resistance remained in villages often located not very far away from where these two parish midwives lived. The geographical distance between mothers and midwives goes some way to explain the spatial pattern of attended births but there were other forces at work that influenced women's decisions. Informal discussions between local and nearby inhabitants regarding the potential advantages and disadvantages of calling a midwife surely played no small role in determining whether she would be summoned or not.

In these two parishes we encounter two midwives with similar social backgrounds who were probably equally well integrated into their respective parishes. There is nothing to suggest that either woman was more skilled than the other and both were equally capable of delivering healthy babies and caring for new mothers. Not surprisingly, the younger Liljeqvist appears to have been somewhat more able than was Holmgren to attend to the needs of those in distant villages. On the other hand, Holmgren could call upon her age and greater experience to appeal to those women who were unaccustomed or hesitant to employ her services. What we are presented with are two similarly skilled and diligent midwives working among two largely identical populations but who, in some cases, achieved markedly different levels of acceptance.

There is no reason to believe that residents in the group of 5 villages where Holmgren found it most difficult to make inroads were unrepresentative of the parish population as a whole. They were no poorer or wealthier, and no less or more educated than their counterparts living in any of the other villages scattered throughout the parish. There was no significant correlation between the occupational structure of the villages and the likelihood that she would be present at births. Similarly, it does not appear that in either parish the age of the mother played any significant role in her decision to call a midwife. ${ }^{66}$

Instead, it is likely that news of the unexpected and uncommon death of Brita Nordstrand, a well-placed woman with a long family history in the area, during childbirth probably undermined local and nearby support for the attending midwife. We should not be surprised that this death, coupled with a disproportionate number of deaths among very young infants in these same villages, caused people to question whether Holmgren's presence at birth offered a safer alternative

66 Although the average age of all mothers differed from village to village, there was no significant statistical correlation between it and the percentage of births attended. 
to that provided by her unlicensed counterparts. These individual assessments of risk and the discussions they evoked counterbalanced the state's considerable efforts to bring academic medicine to all communities of the Sundsvall region. It is unlikely that Holmgren was the only midwife in Sweden who fell victim to public suspicion. These women were undoubtedly highly skilled but their reputations and ability to garner the respect of their clientele determined how successfully they could alter the behaviour of local populations. Even by the late 1800s many had not yet become so ensconced in the medical landscape that their position could withstand a mistake or simple misfortune.

I would like to thank SSHRC (Social Sciences and Humanities Research Council of Canada) for funding the project of which this is a part. Thanks also to the referees of this journal and to Sören Edvinsson for his assistance.

Stephan Curtis is Associate Professor at the Department of History, Memorial University of Newfoundland, St. John's, Canada. 


\section{References}

Bergstrand, Hilding, “Läkarekåren och Provinsialläkareväsendet,” pp. 109-113 in Wolfram Kock ed. Medicinalväsendet i Sverige 1813-1962 (Stockholm, 1963).

Brändström, Anders, and Sören Edvinsson, "Folkhälsans utveckling - tiden efter 1870,” pp. 190-227 in L-G. Tedebrand ed. Sundsvalls Historia, Vol. 2 (Sundsvall, 1997).

Brändström, Anders, Sören Edvinsson and John Rogers, "Did Midwives Make a Difference? A Study of Infant Mortality in Nineteenth-Century Sweden." Paper presented at the European Association for the History of Medicine and Health conference, Oslo, September 3-7, 2003.

Cederschjöld, P.G. Handbok för Barnmorskor (Stockholm, 1822).

Clark-Nelson, M. and J. Rogers, "The Right to Die? Anti-Vaccination Activity and the 1874 Smallpox Epidemic in Stockholm," Social History of Medicine 5 (1992), 369-389.

Clark-Nelson, Marie, "The Year the Children Died: a study of the diphtheria epidemic in Råneå parish, Sweden,” pp. 53-75 in John Rogers ed. Death and the public spheres (Uppsala, 1986).

Coleman, James, Elihu Katz, and Herbert Menzel, Medical Innovation: a diffusion study (Indianapolis, 1966).

Curtis, Stephan, "In-migration and Diphtheria Mortality among Children in the Sundsvall Region during the Epidemics of the 1880s," Journal of the History of Medicine and Allied Sciences 63 (2008), 23-64.

Curtis, Stephan, "Midwives and the Role in the Reduction of Direct Obstetric Deaths during the late Nineteenth Century: the Sundsvall Region of Sweden (1860-1890)," Medical History 49 (2005), 321-350.

Dribe, Martin, and Paul Nystedt. "Information, Trust and the Diffusion of Smallpox Vaccination: the Case of Scania in Sweden, 1802-1835," Scandinavian Economic History Review 51 (2003), 9-29.

Hägerstrand, T., Innovation Diffusion as a Spatial Process (Trans. A. Pred. Chicago, 1967).

Högberg, Ulf, "The Decline in Maternal Mortality in Sweden: the role of community midwifery,” American Journal of Public Health 94 (2004), 13121320.

Högberg, Ulf, S. Wall, and G. Broström, "The Impact of Early Medical Technology on Maternal Mortality in Late 19th-Century Sweden,” Int. J. Gynecol. Obstet. 24 (1986), 251-261.

Kullberg, A., Författningar m.m. angående Medicinialväsendet i Sverige omfattande tiden från och med år 1860 till och med år 1876 (Stockholm, 1877). 
Loudon, Irvine, "Maternal Mortality in the past and its Relevance to Developing Countries Today," American Journal of Clinical Nutrition 72 (2000), (suppl), 241-6s.

Loudon, Irvine, Death in Childbirth: an international study of maternal care and maternal mortality, 1800-1950 (Oxford, 1992).

Mercer, A.J., "Smallpox and Epidemiological Demographic Change in Europe: the role of vaccination," Population Studies 39 (1985), 287-307.

Nilsson, Staffan, "Hur X-strålarna nådde Dalarna och länslasarettet i Falun. Om röntgenteknikens spridning till landsorten kring sekelskiftet”, Nordisk Medicinhistorisk Årsbok, (1994), 123-131.

Pemberton, H. Earl, "The Effect of a Social Crisis on the Curve of Diffusion," American Sociological Review 2 (1937), 55-61.

Rogers, Everett, Diffusion of Innovations (4th ed. Toronto, 1995).

Romlid, Christina, Makt, Motstånd och förändring: Vårdens historia speglad genom det svenska barnmorskeväsendet 1663-1908 (Stockholm, 1998).

Sandblad, Henrik, Världens nordligaste Läkare 1750-1810 (Stockholm, 1979).

Svensson, S., "Bygd och yttervärld. Studier över förhållande mellan nyheter och tradition," Nord. Museets Handlingar 15 (1942).

van Leeuwen, M. et al, HISCO Historical International Standard Classification of Occupations (Leuven, 2002).

Wistrad, H., Författningar angående Medicinal-Väsendet i Sverige (Stockholm, 1860).

\section{Primary Sources}

Bidrag till Sveriges Officiella Statistik (BiSoS) Series K (1861-81).

INDIKO Database - Demographic Data Base, Umeå University.

Files created by the Demographic Data

Sundsvalls-Posten \# 30, 24 February, 1890.

\section{Härnösand Landsarkiv [Härnösand Regional State Archive]}

Förste Provinsialläkarens i Västernorrlands län, "Barnmorskors dagböcker”Series D III:I. Tuna and Indal parishes.

"Kongl. Medicialstyrelsens cirkulär till barnmorskorna i riket, angående försigtighetsmått, som böra af dem iakttagas till förekommande utfärdadt den 13 Juni 1881.”Första Provincialläkaren i Vasternorrlands län. Barnmorskors dagböcker. Series D III

\section{Medelpadsarkivet [The Medelpad Archive]}

Series A1:2. Indahls Kommun Kommunalstämma protokoll (12 December, 1880). 


\section{Riksarkivet [National Archive]}

Årstrycket 1819, Nr. 18. "Reglementet för barnmorskor."

Medicinal Styrelsen. Series E5A, 'Årsberättelser från provinsialläkare.’ Vols. VIII (1881), XIV (1884) and XXIV (1889). Reports from provincial doctor in Sundsvall. 